REV. BOGDAN ZBROJA

\title{
Topicality of the Second Vatican Council Constitution Dei Verbum in Contemporary Biblical Studies
}

The Dogmatic Constitution on Divine Revelation Dei Verbum of the Second Vatican Council is an epoch-making step for the progress made in studies on the Holy Scripture. The development of Biblical Studies reaches its apogee in this particular document, at the same time giving directions for further search for the essence of God's plan presented in the words of hagiographers.

After the publication of this conciliar document a few other crucial texts were released, which lead to broadening the knowledge of the Bible in which God expressed His teachings in a human way, with the use of different literary genres and through hagiographers. ${ }^{1}$ The aforementioned documents are three texts prepared by the Pontifical Biblical Commission: The Interpretation of the Bible in the Church, The Jewish People and Their Sacred Scriptures in the Christian Bible and The Bible and Morality. Among important publications one also needs to mention the Post-Synodal Apostolic Exhortation Verbum Domini of Benedict XVI and an important tool for the development of faith which is the Catechism of the Catholic Church, promulgated by John Paul II on the $30^{\text {th }}$ anniversary of the Second Vatican Council.

${ }^{1}$ Cf. Second Vatican Ecumenical Council, Dogmatic Constitution on Divine Revelation Dei Verbum, no. 12. 
Each of these documents contains some fundamental ideological element deriving from the conciliar thought of Dei Verbum, adding, however, an element of new understanding, research fields or methods of analysis of biblical texts. We will try to have a closer look at the influence the Constitution on Divine Revelation had on the world of academic research on the Bible after the Second Vatican Council. This article will first cover the Revelation of God and his plan of salvation of man, then it will talk about passing on the deposit of faith that was expressed by hagiographers in the Holy Scripture and, lastly, it will elaborate on the necessary response of every man to God's invitation to participate in the dialogue with the vivifying Word of God.

\section{In His goodness and wisdom God chose to reveal Himself ${ }^{2}$}

Inconceivable in his being by any other creature, God decided to present His own nature to the creations that He had brought to life on earth in time and space. He did it in a way that made it possible for the beings created by Him to accept the truth about Him and His salvific will, since He had equipped them with wisdom to do so. God revealed Himself to people many times and in many ways, to finally speak to people through His beloved Son (cf. Heb 1:1-2). This dialogue, initiated by God, is a completely natural environment, thanks to which man can become familiar with God and who He is by nature, by means of the dialogue in Christ, through the Word that God addresses to people and the response from man that He receives. ${ }^{3}$ Benedict XVI in his Apostolic Exhortation Verbum Domini emphasises this particularly important aspect of the Word of God, which lies at the foot of the united Europe. The monastic culture, which was the inspiration for the Christian roots of the Old Continent, came from nothing else but fascination of man with the Word of God,

${ }^{2}$ Cf. ibidem, no. 2.

${ }^{3}$ Cf. Benedict XVI, Post-Synodal Apostolic Exhortation Verbum Domini, no. 6. 
recorded in the Bible. ${ }^{4}$ We can therefore see the biblical foundations of European culture at the very beginning of its existence. The Constitution on Divine Revelation Dei Verbum brings a new wave of the "famine for hearing the word of the Lord" (cf. Am 8:11), which has been present in the global society for the last 50 years, especially in Europe.

The conciliar Constitution says much about the way in which God addresses people through the Bible and Tradition: God speaks in the Sacred Scripture to men and in human fashion, ${ }^{5}$ which shows the marvellous "condescension" of the eternal wisdom of His Revelation ${ }^{6}$ in order to adapt to human perception possibilities and current level of culture development. We need do emphasise that despite the great scientific development that the world experienced over the last few centuries, the willingness to understand what God has to say to people did not follow. The contemporary man is not much interested in God Himself, or in what he has to say to people. The dwellers of the world come up with countless fields of scientific research to which they put their minds, at the same time not responding to the salvific dialogue with the Incarnate Word. ${ }^{7}$ The Council reminds that "one does not live by bread alone, but by every word that comes forth from the mouth of God" (Mt 4:4) and encourages to look further and higher.

In the Post-Synodal Exhortation Verbum Domini Pope Benedict XVI talks a lot about coming closer to God "speaking" to man as a friend and inviting him and taking him into the fellowship with Himself. God is the One, who addresses men with words - with His words He creates, orders and heals everything. Whatever comes from this "verbalised" design of God is either good or very good (cf. Gen 1). We can therefore talk about the cosmic and the eschatological dimension of the Word, its power of

${ }^{4}$ Cf. ibidem, no. 32 .

${ }^{5}$ Cf. Second Vatican Ecumenical Council, Dogmatic Constitution on Divine Revelation Dei Verbum, no. 12.

${ }^{6}$ Cf. ibidem, no. 13.

${ }^{7}$ Cf. Pontifical Biblical Commission, The Bible and Morality. Biblical Roots of Christian Conduct, I, 5.1b. 
creation and realism of discourse. ${ }^{8}$ The first way in which God spoke to man of all times is the divine work of creation, made by the spoken Word - Logos: "God said [...] and there was" (Gen 1:3). Also after the sin in paradise God says the Word to the fallen man: "where are you?" (Gen 3:9), proving that $\mathrm{He}$ is the one to speak first, uttering the Word that has the power to heal the man, who had lost the battle with the Satanic temptation, and is in the state of sin and death.

An important element of understanding the idea of the hagiographers is deciphering the sense behind their words. Since the Bible was written with the inspiration of the Holy Spirit, it has two basic dimensions: literal and spiritual. The latter includes three more sub-dimensions: allegorical, moral and anagogical. Therefore, these four basic dimensions of the Sacred Scripture contain the greatest message of the Word of the Lord, which in these basic senses teaches the man about the truth of salvation. The Catechism of the Catholic Church, which in itself is a summary of the $30^{\text {th }}$ anniversary of the conciliar renewal, contains a famous Latin couplet: "Littera gesta docet, quid credas allegoria, Moralis quid agas, quo tendas anagogia." "When familiar with the Bible, one can understand better what was said by God about the salvation of man. It cannot, however, happen without the analogy of faith, understanding of different literary genres, accepting the unity of the biblical content and the living tradition of the Church.

\section{The hagiographers committed the message of salvation to writing ${ }^{10}$}

The teaching of the conciliar Constitution Dei Verbum aims at presenting the content of the Sacred Scripture. The hagiographers wrote down

\footnotetext{
${ }^{8}$ Cf. Benedict XVI, Post-Synodal Apostolic Exhortation Verbum Domini, no. 6-21.

${ }^{9}$ Catechism of the Catholic Church, no. 118: "The Letter speaks of deeds; Allegory to faith; The Moral how to act; Anagogy our destiny."

${ }^{10}$ Cf. Second Vatican Ecumenical Council, Dogmatic Constitution on Divine Revelation Dei Verbum, no. 7.
} 
only the words that God wanted them to hand on to man for his salvation. That is why the Books of the Bible teach the truth that was preserved of God's will and for our salvation in a certain and faithful way. ${ }^{11}$

Blessed John Paul II, making an introductory speech on the document of the Pontifical Biblical Commission entitled The Interpretation of the Bible in the Church, pointed out that interpretation of the Sacred Scripture is of great significance both for the Christian faith and the life of the Church. ${ }^{12}$ It means that the analysis of the sense that God included in the inspired words, which contemporary men are in contact with through the Bible, is of paramount importance both for those who receive the words of God and for their lives - it is the moral conduct of the faithful. The Pope points out an important truth, which is present in the diversity of forms of the Words of the Lord. For many, it is difficult to understand the intention of God since they misinterpret the Absolute, or even negate it. Assuming that God is a being that does not accept diversity and destroys everything that stands in its way is contradictory with the idea of God in the Bible, who is perceived as the Creator of all forms of life: spiritual, intellectual, moral and physical.

An important rule advocated by John Paul II is for the biblicists to assist the faithful in finding in the Sacred Scripture the living Word of the Lord, possessing the power of unifying human souls with God the Saviour. According to the Pope, another crucial thing is promoting the biblical thought among contemporaries, in order to facilitate the salvific work of the power included in the sacred texts. A deep thought of the then Cardinal Joseph Ratzinger needs to be mentioned here, who, in the preface to the Interpretation of the Bible in the Church, says: "I believe that this document is very helpful for the important questions about the right way of understanding the Holy Scripture and that it also helps us to go further." ${ }^{13}$ It seems that the aim of this document is discovering

${ }^{11}$ Cf. ibidem, no. 11.

${ }^{12}$ Cf. John Paul II, Address on the occasion of the celebrations of the first centenary of the encyclical Providentissimus Deus and the 50th anniversary of the encyclical Divino Afflante Spiritu, "Acta Apostolicae Sedis. Commentarium Officiale” 86 (1994), p. 232.

${ }^{13}$ The Interpretation of the Bible in the Church, Preface. 
the right way of understanding the content of the Sacred Scripture and noticing the new horizons of the inspired Word. J. Ratzinger in his statement touches on the mental process that takes place inside the addressee of the sacred text, and what the Word of God inspires him to do. From the altered personality of the "new man," who is inspired by the Word of Revelation, comes concrete action for the sake of his salvation, as well as the salvation of others redeemed by Jesus Christ.

The Interpretation of the Bible in the Church is divided into four parts. Firstly, it discusses the most basic methods and approaches to Bible interpretation, then it refers to hermeneutic issues and, finally, to specific dimensions of the Catholic interpretations of the Bible and their reference to the life of the Church. Each of these main sections is divided into sub - sections, which present the views of the members of the Pontifical Biblical Commission on different issues, as well as the needs of contemporary Biblical Studies, in a deeper, more detailed way. The conciliar biblical renewal that Dei Verbum encourages when it discusses the accessibility of the Bible and number of professional commentaries on the Bible, ${ }^{14}$ has its historical confirmation here. As far as the methods and approaches to the Sacred Scripture interpretation are concerned, the Biblical Commission began its analyses with the presentation of the historical-critical method. It is a basic but crucial research tool in Biblical Studies, ${ }^{15}$ although it is currently criticised by many. Apart from this one, other methods are used: rhetorical, narrative and semiotic. The canonical approach, which reaches for the Jewish traditions of interpretation, is also well known, as well as the approach concerning the history of text interaction. ${ }^{16}$

It is extremely important for the Biblical Studies to turn to the Tradition present in the community of the believers in the Church from the very beginning, rather than the 'bible-centrism' of contemporary believers' lives. Currently people do not feel like subordinating their thoughts and discoveries to the judgement or supervision of anyone, especially not

${ }^{14}$ Cf. Second Vatican Ecumenical Council, Dogmatic Constitution on Divine Revelation Dei Verbum, no. 22.

${ }^{15} \mathrm{Cf}$. Pontifical Biblical Commission, The Interpretation of the Bible in the Church, I, A.

${ }^{16} \mathrm{Cf}$. ibidem, I, B-C. 
the Church and her Magisterium. That is why there is a risk of millions of interpretations of the inspired text, interpretations that have no reference to Tradition or ecclesiastical spirit. There exists a close connection and communication between the Sacred Tradition and the Sacred Scripture, ${ }^{17}$ for they merge into a unity of God Revelation. According to the Constitution Dei Verbum "Sacred tradition and Sacred Scripture form one sacred deposit of the word of God, committed to the Church." ${ }^{18}$ One should therefore not be separated from the other, since then there is not one deposit of the word of God, but there are two. And there is only one Revelation, like there is one God, who speaks to man in a human fashion, hoping to initiate the dialogue between man and Himself.

It is common knowledge that the Bible consists of two main parts: the Old and the New Testaments, which are, however, unified in accordance with the rule defined by Saint Augustine: "Novum in Vetere latet et in Novo Vetus patet." ${ }^{19}$ According to the Constitution Dei Verbum, the Old Testament prepares for the coming of Christ, announces this coming by prophecy and indicates its meaning, ${ }^{20}$ whilst the New Testament states that the kingdom of God on earth was established by Christ. ${ }^{21}$ Since the Sacred Scripture consists of texts that come from different times and places in the history of mankind, the biblical renewal focuses not only on the better understanding of the Gospel and Jesus, but also on everything that helps to understand the divine plan of salvation expressed through the signs and images of the texts of the Old Covenant, as understanding the Old Testament conditions the right interpretation of the message presented by the New Testament.

${ }^{17}$ Cf. Second Vatican Ecumenical Council, Dogmatic Constitution on Divine Revelation Dei Verbum, no. 9.

${ }^{18}$ Ibidem, no. 10.

${ }^{19}$ Catechism of the Catholic Church, no. 129: "the New Testament lies hidden in the Old and the Old Testament is unveiled in the New"; cf. Second Vatican Ecumenical Council, Dogmatic Constitution on Divine Revelation Dei Verbum, no. 16.

${ }^{20}$ Cf. Second Vatican Ecumenical Council, Dogmatic Constitution on Divine Revelation Dei Verbum, no. 15.

${ }^{21}$ Cf. ibidem, no. 17. 
Sacred biblical authors, with the use of their human words, wrote down the Word of God, which has the power to alter the whole man, the power to introduce him to the mystery of salvation completed by the Incarnate Word - Jesus Christ. One can notice that the hagiographers faithfully followed the Word of God, in order not to falsify it in any way and serve the Revelation of the Lord. They never attempted to alter the Word, their role was only to communicate it to everyone who wants to stop and brood over the texts they had written down. They created their works under the inspiration of the Holy Spirit, basing them on their own considerations, ways of communication and literary rules prevailing in their times, keeping the readers they were addressing in mind (cf. Lk $1: 1-4)$. One can therefore be certain that what can be found in the Bible is actually the Word of God, the Word that He speaks to His creation in the salvific dialogue, the creation on which he wishes to bestow a communion with Him, through His presence in the Eucharist and the Bible. This communion will be eschatologically fulfilled when the man fully understands the intention of God in His eternal kingdom.

Since the texts written under the inspiration of the Holy Spirit are available to us, we must also consider the consequences that the Constitution Dei Verbum had for the contemporary world. The Bible, its worthy interpretation, as well as methods and approaches to its interpretation, require some action on the side of man. As one can have the Bible on the shelf in his house, or, as it happens more and more often, downloaded to his computer, e-book or other multimedia device, one can own it, but never really read it. And sometimes, even if he reads it, the questions arise if he puts its words into practice, if he learns from it a new way of thinking and living in accordance with the revealed rules. The Dogmatic Constitution on Divine Revelation Dei Verbum put a lot of effort in making sure that the Bible can become a constant element of contemporary people's lives, as "ignorance of the Scriptures is ignorance of Christ."

${ }^{22}$ Second Vatican Ecumenical Council, Dogmatic Constitution on Divine Revelation Dei Verbum, no. 25; St. Jerome, Commentary on Isaiah, Prol., PL 24, 17. 


\section{The obedience of faith is to be given to God who reveals ${ }^{23}$}

It seems obvious that God who reveals Himself to man needs to be listened to. Seeing the immensity of grace and the wisdom of the Word which, through the Bible and the Tradition, has been animating people over the centuries, knowing the various ways in which God communicates with people, we must notice God's "humbleness" in the dialogue with His creation.

The conciliar Constitution Dei Verbum states that the Church, taught by the Holy Spirit, is concerned to move ahead towards a deeper understanding of the Sacred Scriptures. ${ }^{24}$ These words express probably the most important human activity, which is making attempts to understand the inspired words of God. In order to do it in the best possible way and avoid making mistakes in the process, it is necessary to apply the methods of Bible interpretation that the document of the Pontifical Biblical Commission describes. The right methods and approaches are crucial, in order to make it possible to understand the inspired Scripture. On the other hand, constant broadening of one's horizons is necessary, in order for the human mind to be able to understand even more precisely what God wanted to say through the hagiographers. In the spirit of the conciliar Constitution, it is our obligation to 'modernise' the methods and approaches to the Sacred Scripture and constantly develop our abilities to interpret what we received from God.

Another important indication of the conciliar Constitution Dei Verbum concerns the fact that the Church has always venerated the divine Scriptures, just as she venerates the body of the Lord. ${ }^{25}$ Veneration of the Word of God is, most importantly, connected with liturgy. In the Eucharistic liturgy we encounter two sources of grace coming from Christ

${ }^{23}$ Second Vatican Ecumenical Council, Dogmatic Constitution on Divine Revelation Dei Verbum, no. 5 .

${ }^{24}$ Cf. ibidem, no. 23.

${ }^{25}$ Cf. ibidem, no. 21. 
Himself which are His Body and Blood, connected inseparably with His Word. None of the seven sacraments that the Church has at her disposal happens without the Word of God. It is therefore clear that the Church has always venerated the Word of the Lord, as well as the Eucharist. ${ }^{26}$ Veneration of the Word of God should be exercised by regular reading of the Sacred Scripture, but also by the obedience to the voice of the Church, which has been entrusted exclusively with the task of authentic and worthy interpretation the Word of God. This authority is exercised in the name of Jesus Christ, and the teaching office is not above the Word of God, but serves it, teaching only what has been handed on and guarding it scrupulously. ${ }^{27}$

The Church encourages the believers to commune with the Bible, as through the reading and study of the sacred books the Word of God may spread rapidly and be glorified. ${ }^{28}$ The Conciliar Fathers point to the reading and study, which should take place in the spirit of the Church. It is important to read first and only later - study. The act of "inhaling" in one's mind the Word of God is emphasised. This same Word is then "digested" by the reasonable analysis of the accepted Word. These two actions, however, cannot be reversed. One cannot first analyse and then read the Word of God, as this might a priori impose a way of interpretation constricting the Word of God, instead of opening one's mind to what God wants to pass on the reader.

Reading the Word of God and understanding what the Lord is trying to communicate to men is integrally connected with the way of life of the "man of the Word." It is not enough to hear what God said and not fulfil His will. In the Gospel according to Matthew, Jesus tells the story of two sons, whose father ordered them to go and work in his vineyard (cf. Mt $21: 28-32$ ). One of them said in reply: "Yes, sir," but did not go (v. 30), the other one said: "I will not," but afterwards he changed his mind and

${ }^{26}$ Cf. Pontifical Biblical Commission, The Bible and Morality. Biblical Roots of Christian Conduct, I, 3.4.1b.

${ }^{27}$ Cf. Second Vatican Ecumenical Council, Dogmatic Constitution on Divine Revelation Dei Verbum, no. 10.

${ }^{28}$ Cf. ibidem, no. 26. 
went (v. 29). The second one in fact did what his father had asked them to do, although in the beginning he did not want to. In our approach to the Word of God one must above all gather all his strength and focus on fulfilling the will of the Lord, which is shown in the Bible and in the Tradition - the Revelation of the Lord. This necessity of putting the Word read in the Bible to reality is elaborated on in another document of the Pontifical Biblical Commission entitled The Bible and Morality. ${ }^{29}$

\section{Conclusions}

Having presented the ways in which the Dogmatic Constitution on Divine Revelation Dei Verbum prepared by the Second Vatican Council affects the interpretation of the Sacred Scripture, summing up the conclusions reached in this analysis seems to be in place. The most important issue that needs to be emphasised is that, according to the Conciliar Fathers, "we now await no further new public revelation before the glorious manifestation of our Lord Jesus Christ." ${ }^{30}$ The most basic conclusion is that everything that is necessary for salvation is included in the Revelation of God: the Sacred Scripture and the Tradition of the Church. That is why it is crucial to analyse both the Bible and the Tradition. An important contribution in the process is the work of extraordinary biblicists - the members of the Pontifical Biblical Commission, as well as the authority of Pope Benedict XVI - the author of the Post Synodal Apostolic Exhortation Verbum Domini.

The most important sign of the topicality of Dei Verbum in contemporary Biblical Studies is the wide-spread and fruitful promotion of the Word of God in all fields of human activity, in the world of media, entertainment and also academic research. The world of art and culture

${ }^{29}$ Cf. Pontifical Biblical Commission, The Bible and Morality. Biblical Roots of Christian Conduct, II, 1.1.3 and II, 1.2.3.

${ }^{30}$ Second Vatican Ecumenical Council, Dogmatic Constitution on Divine Revelation Dei Verbum, no. 4. 
should not be overlooked either, as strong bonds between the artistry of the human heart and the Word of God can be noticed.

The second dimension of the topicality of the Constitution is the necessity of constant modernisation of analytical techniques and methods that all documents of the Magisterium emphasise. The newest scientific accomplishments need to be applied in Biblical Studies. The aim in mind is to make sure the text written with the inspiration of the Holy Spirit will be understood by the contemporary man, and will touch on issues important for him nowadays, giving him answers to problems that trouble him. The Bible is the book of life, written centuries ago, but always up to date, as it shows man in his earthly environment which is entered by God the Saviour and the Creator. ${ }^{31}$

The key message of both the Constitution on Divine Revelation and subsequent important commentaries of different Church figures is the fact that, through well guided reading and interpretation of the Word of God, all men of all times can meet with God, since, through divine revelation, God chose to show forth and communicate Himself and the eternal decisions of His will regarding the salvation of men (Dei Verbum, 6). The Word of God, read in the spirit of the Church, leads to the encounter between man and God, who first speaks to men in partial and various ways through the prophets, and then in His Son (cf. Heb 1:1-2; Dei Verbum, 4).

What direction are the Biblical Studies of the $21^{\text {st }}$ century going to take? This question needs to be thought over and answered with much consideration. The Second Vatican Council and its Dogmatic Constitution on Divine Revelation Dei Verbum constitute a necessary point of reference for all those who love the Word.

KS. BOGDAN ZBROJA

${ }^{31}$ Cf. B. Zbroja, Bóg - Zbawca i Wybawiciel, [in:] Z badań nad Biblia, vol. 7, Kraków 2003, p. 93-103. 


\section{Summary}

\section{Topicality of the Second Vatican Council Constitution Dei Verbum in Contemporary Biblical Studies}

The article discusses the issue of how strongly contemporary ecclesiological and scholarly approach to the Sacred Scripture is rooted in the Second Vatican Council Constitution Dei Verbum. The Bible originates from the faith of the Church, and, together with Tradition, helps to build this faith. The text consists of three sections. The first one focuses on God, who reveals Himself and His plan of salvation to man. Then, the ways in which God communicates with man through human authors and the long process of writing the inspired sacred books are mentioned. The last part emphasises how important it is for man to respond to the Word of God, which will enable the salvific dialogue of man with his Father, through His Son in the Holy Spirit. The community of Church faith is a natural environment of research, devotional reading and encounters with the Word of God, which are the elements of Christian life that the Constitution Dei Verbum (no. 25) encourages to implement.

\section{Keywords}

Second Vatican Council, Constitution Dei Verbum, Pontifical Biblical Commission, Benedict XVI, Exhortation Verbum Domini, Biblical Studies, topicality

\section{Streszczenie}

\section{Aktualność Konstytucji Dei Verbum Soboru Watykańskiego II we współczesnej biblistyce}

Artykuł traktuje o zakorzenieniu konstytucji o Bożym Objawieniu Soboru Watykańskiego II we współczesnym naukowym i eklezjologicznym podejściu do Pisma Świętego. Biblia bowiem wyrasta z wiary Kościoła i tę wiarę, wraz z Tradycją, buduje. Całość opracowana jest w trzech punktach. Najpierw uwaga skupia się na Bogu, który objawia człowiekowi samego siebie i swą wolę zbawienia ludzkości. Następnie jest mowa o sposobach ko- 
munikowania się Boga z człowiekiem przy pomocy autorów ludzkich oraz długi proces tworzenia dzieł natchnionych kanonu ksiąg świętych. Jest wreszcie podkreślona konieczność odpowiedzi człowieka na Boże Słowo, dzięki czemu istota ludzka wchodzi w dialog zbawczy ze swoim Ojcem, przez Jego Syna w Duchu Świętym. Wspólnota wiary Kościoła stanowi naturalne środowisko badań, lektury i życia Słowem Bożym, do czego zachęca w swoim zakończeniu Konstytucja Dei Verbum (nr 25).

\section{Słowa kluczowe}

Sobór Watykański II, Konstytucja Dei Verbum, Papieska Komisja Biblijna, Benedykt XVI, Adhortacja Verbum Domini, biblistyka, aktualność 